ИГНАТОВСКИЙ Ярослав Ринатович - политолог, генеральный директор аналитического центра «ПолитГен» (Россия, Санкт-Петербург; hindutime@таil.ru)

\title{
РОЛЬ ЦИФРОВИЗАЦИИ В ТРАНСФОРМАЦИИ РОССИЙСКОГО ПОЛИТИЧЕСКОГО ПРОТЕСТА
}

\begin{abstract}
Аннотация. В рамках исследования были выявлены четыре ключевых тенденции, характеризующие влияние цифровизации на российский политический протест. Первая состоит в том, что социальные сети Рунета стали инструментом протестной мобилизации различных сегментов российского общества. Вторая тенденция заключается в том, что цифровизация способствовала росту протестных настроений молодежи. Третья тенденция показывает возможности ретрансляции протестных настроений в виртуальную плоскость. Четвертая тенденция - всплеск активности российской несистемной оппозиции, получившей возможность формировать собственную альтернативную политическую повестку дня посредством соцмедиа Рунета.

Ключевые слова: цифровизация, политический протест, протестные настроения, симулятивная реальность, «цифровые аборигены», Рунет
\end{abstract}

Актуальность исследования обусловлена, во-первых, сложными и разнонаправленными трансформациями политического пространства современной России, в рамках которого в последнее время (2018-2020 гг.) происходит всплеск протестных настроений и выступлений. Причем указанные протестные проявления протеста носят как собственно политический, так и более широкий - социальный - характер, связанный с формированием новых «точек» локальной конфликтности.

Во-вторых, не менее значимый фактор - радикальное изменение информационного ландшафта российского социума, которое стало особенно очевидным к середине 2010-х гг. Можно говорить, что мы вступили в эпоху соцмедиа, в которой превалируют горизонтальные и диагональные коммуникации, резко возрастает роль самоорганизующихся сообществ в виртуальном пространстве Рунета.

В-третьих, серьезным фактором, заставляющим обратиться к данной проблематике, является системный кризис коммуникации «власть - общество» (причем на всех уровнях организации публичного управления - федеральном, региональном, местном) в сочетании с отсутствием сколько-нибудь позитивного общенационального образа будущего. Нелишне отметить, что указанная ситуация тотальной неопределенности («новая нормальность») серьезно усугубилась в условиях пандемии COVID-19.

Степень научной разработанности темы исследования. Указанная проблематика занимает серьезное место в отечественных и зарубежных научных исследованиях. По нашему мнению, в ее рамках можно выделить три пласта работ.

Первый и, безусловно, наиболее разработанный пласт составляют исследования, посвященные природе и характеру современного политического протеста [Шатилов 2014; Карзубов 2016; Пономарев, Белов, Майлис 2018 ]. Второй пласт - роль новых форм политической коммуникации в трансформации макросоциальной динамики и, в частности, политических процессов. В указанном контексте, безусловно, наибольший интерес представляют труды Дж. Коэна, Э. Шмидта, С.В. Володенкова, А.А. Косорукова [Коэн, Шмидт 2013; Володенков 2019; Косоруков, Котлярова 2018] и др. Третий, наименее изученный пласт - комплекс новейших отечественных исследований, посвященных взаимосвязи протестных настроений, выступлений и цифровизации в политических реалиях сегодняшней России [Пырма 2019; Козлова 2020; Титов 
2020]. Представляется, что указанное направление, в рамках которого пересекаются «цифра» и политический протест, нуждается в дальнейшем развитии и серьезной теоретико-методологической проработке.

Проблема данного исследования может быть обозначена как анализ влияния фактора цифровизации на политический протест в сегодняшней России.

Теоретико-методологические основания данного исследования были выработаны путем сочетания современных концепций протеста в различных его формах и проявлениях (включая его цифровое измерение), а также новейших исследований российских ученых, посвященных влиянию цифровизации на политическое пространство и динамику общества.

Обсуждение проблемы. Можно справедливо полагать, что указанная проблема имеет двусторонний, симбиотический характер. С одной стороны, речь идет о развитии новых форм коммуникации как таковых, форсированной «интернетизации» российского общества. С другой стороны, в рамках данного подхода нельзя не упомянуть как общеизвестные (пенсионная реформа, падение реальных доходов большинства граждан, хамство чиновников, ставшее общеизвестным благодаря соцмедиа), так и менее очевидные факторы. Среди них важное место занимают такие, как кризис образа будущего, политико-психологический эффект усталости от «стабильности/стагнации» власти, смена политических поколений, алармистский образ настоящего, создаваемый массмедиа и на телевидении, и в интернет-пространстве.

Естественно, взаимодействуя друг с другом, все указанные негативные факторы (многие из них, например неэтичное поведение местных чиновников, носят локальный характер, представлены «в единичном числе» и не способны повлиять на протестную динамику российского социума) выступают интегративным драйвером протестных выступлений, создают кумулятивный эффект роста конфликтности в офлайн- и онлайн-среде.

Первый и наиболее понятный момент, связанный с цифровизацией протестной активности россиян, обусловлен «уходом» значительной их части в цифровую среду. В большой степени это касается и сегмента несогласных с действующей властью, причем речь идет о неприятии не только проводимого политического курса, но и действий местных чиновников в сфере жилищнокоммунального хозяйства, развития социальной инфраструктуры, экологии. В данном ракурсе достаточно упомянуть события в Шиесе, несостоявшееся строительство храма в Екатеринбурге, конфликтные ситуации вокруг мусорных полигонов Кучино и Ядрово в Московской обл.

Важно учитывать, что решающим фактором «виртуализации» подобных протестов в середине - конце 2010-х гг. стало не распространение Интернета как такового (которое достаточно активно происходило в России уже в середине конце нулевых годов). Главным стало развитие социальных сетей Рунета, «виртуальных сообществ» в сочетании с массовым доступом россиян - и несогласных, и согласных - к мобильным инструментам интернет-коммуникации, прежде всего относительно недорогим смартфонам.

Второй момент, о котором необходимо сказать особо, связан с формированием цифровой субъектности «цифровых аборигенов», поскольку именно молодежь является основным носителем и в то же время агентом распространения цифровых технологий. В частности, Е.В. Бродовская приводит следующие данные: «...согласно результатам научного проекта Финансового университета при Правительстве РФ "Влияние цифровизации на профессиональную культуру российской молодежи” 2018 г., большинство молодых людей в России являются настоящими аборигенами цифрового пространства, о чем свидетельствует довольно ранний старт в использовании интернет-коммуникации: $25 \%$ 
в 7-10-летнем возрасте; 45,5\% - в 10-13-летнем возрасте; еще четверть - в возрасте старше 13 лет. При этом самая существенная доля молодых россиян проводит треть дня в социальных медиа: 40\% - 4-8 ч; 34\% - 1-4 ч; $15 \%-8-$ 12 ч; $6 \%$ - более 12 ч» [Бродовская 2019: 65].

Говоря о непосредственном влиянии фактора цифровизации на российский политический протест, на наш взгляд, можно выделить четыре ключевые тенденции.

Первая заключается в том, что социальные сети Рунета стали эффективным инструментом политической мобилизации и, в меньшей степени, координации действий протестующих. Естественно, этот факт существенно повысил мобильность протестных действий: на первом этапе (2010-2016 гг.) властные структуры не успевали превентивно реагировать на подобные выступления. Впервые данная тенденция наиболее ярко проявилась в ходе «восстания Спартака» в конце 2010 г. (события вокруг ТЦ «Европейский») и еще более рельефно - в ходе «Болотных» событий 2011-2012 гг.

Сегодня можно наблюдать несколько иную картину: государственные структуры, резко усилив мониторинг политического сегмента Рунета, существенно снизили и «взрывной» характер (внезапность и скорость организации) протестных акций, и мобилизационный потенциал социальных сетей как таковой. Однако необходимо учитывать, что подобная тактика, направленная на усиление мониторинга соцмедиа, не всегда эффективна в силу как минимум трех причин.

Первая состоит в активном развитии соцмедиа в последние годы (в частности, таких, на первый взгляд, «аполитичных» peсурсов, как Instagram, TikTok, Яндекс.Дзен), что неизбежно открывает новые возможности политической мобилизации. Вторая причина связана с трендом локализации протеста на местном уровне, который наметился в России с 2018 г. В этих условиях возникает чисто техническая трудность раннего выявления лакун (сообществ), аккумулирующих протестные настроения. Третья причина - все более заметный тренд символической мобилизации, которая или не предполагает текстов как таковых или использует их в минимальном объеме, а ориентирована на графический контент и мемы. Пожалуй, наиболее яркий пример 2020 г. - мем, широко распространившийся в социальных сетях, «покорми голубей», который стал символом мобилизации различных групп российской несистемной оппозиции на основе наиболее общих антивластных - «гражданских» - требований (отмена пенсионной реформы, отмена поправок к Конституции РФ, честные выборы и т.п.).

Вторая тенденция связана с тем, что цифровизация социальной жизни стала безусловным драйвером политизации молодежи, особенно в Москве, СанктПетербурге и других крупных городах. Именно молодежь, проживающая в крупных и средних городах, сегодня выступает наиболее активным протестным сегментом общества. Данная ситуация серьезно отличается, например, от событий 2011-2012 гг., когда наряду с молодежным сегментом движущей силой выступлений против действующей власти были «норковые шубы», ранее обозначенные в западной политической науке как frustrated achievers [Graham, Pettinato 2002]. Это люди 35-45-летнего возраста, достигшие серьезного (по российским меркам) материального благосостояния и ориентированные на иные политические ценности (справедливость, уважение со стороны власти, правовое государство).

Можно согласиться с мнением, что «важнейшими мотивационными факторами, стимулирующими социальный протест российской молодежи, являются дефицитарная потребность в формировании позитивного образа буду- 
щего и психоэмоциональное ощущение “несправедливости” существующего социального порядка. Их дополняет установка на восприятие обобщенного института “государства" (действующей власти, политиков, чиновников всех уровней) как коррумпированного, неэффективного и в силу этого неспособного справиться с многочисленными социально-экономическими вызовами и негативными тенденциями современности» [Титов 2020: 155].

При этом отмечается следующее: практики протеста цифровых аборигенов, представляющих поколения $Y$ и $Z$, несколько разнятся. В частности, для последних более характерна модель неструктурированного политического протеста «против всего», отсутствие или минимизация рациональных аргументов недовольства, а также четкого объекта протестной активности (те, на кого направлено это недовольство). В то же время «игреки» в существенно большей степени ориентированы на локальные протесты и готовы в них участвовать, т.е. выступать против того, что негативно влияет на их жизнь и жизнь их близких.

Однако следует упомянуть и то, что «сетевой» образ жизни значительной части молодежи, в т.ч. критически настроенной по отношению к действующей власти, способствует частичному рассеиванию и уменышению силы «уличных» выступлений.

Таким образом, можно говорить и о третьей важной тенденции, характеризующей влияние «цифры» на политическую активность в целом и на протестную динамику в частности. Речь идет о том, что соцмедиа Рунета, всевозможные мобильные «гаджеты» выступают инструментом не только мобилизации, но и ретрансляции политического протеста в онлайн-пространство, дают возможность его перевода преимущественно в виртуальную плоскость. Несомненно, подобная ситуация выгодна действующей власти, поскольку позволяет эффективно «увести» недовольство из физической плоскости: сначала канализировать его в многочисленных интернет-сообществах и группах (что приводит к фрагментации и, как правило, не позволяет протестующим консолидировать усилия), а потом эффективно «растворить» в виртуальном пространстве. Указанный феномен еще в целом недостаточно изучен ни в политической науке, ни в социологии массовых коммуникаций, но уже замечен и частично описан отдельными политтехнологами и исследователями («сетевые хомячки», «Диванные войска») [Шатилов 2014].

Тем не менее необходимо понимать, что в сегодняшних российских реалиях тенденция ретрансляции протестных настроений в виртуальную среду хотя и снижает риски для действующей власти «здесь и сейчас», также способствует формированию общего негативного психоэмоционального фона в социуме, выступает катализатором общего недовольства среди различных слоев российского общества.

И наконец, четвертая, крайне важная тенденция связана с тем, что развитие цифровых коммуникаций стало существенным фактором политического возрождения российской несистемной оппозиции, обретения ею собственного информационного лица. При этом представляется, что в данном контексте наиболее важную роль сыграли не социальные сети, мессенджеры и блогосфера (политическое значение которой, по нашему мнению, снизилось), а видеохостинг YouTube, ставший универсальной платформой для создания политического видеоконтента. Такое развитие событий привело к конструированию в российском медиапространстве альтернативной политической повестки дня, предлагаемой лидерами несистемной оппозиции.

Важным следствием активизации несистемной оппозиции на «цифровой» основе стало то, что она получила возможность искусственно интегрировать события локального масштаба (уже упомянутые выше протесты местного 
характера, в большинстве случаев не направленные против федеральной власти) в большую общероссийскую повестку дня. Это, в свою очередь, позволяет придать любым выступлениям социального характера выраженный политический окрас, а через некоторое время - выстраивать панораму «протестующей» России, в которой большинство населения недовольно властью и требует ее смены.

Bыводы. В рамках проведенного анализа нами была предпринята попытка выявить влияние фактора цифровизации на особенности политического протеста в сегодняшней России.

Во-первых, можно отметить, что развитие социальных медиа Рунета, их политического сегмента явилось одним из факторов роста протестных настроений в российском обществе, способствовало формированию сетевых протестных сообществ, активность которых не всегда ограничивается пределами виртуальной среды.

Во-вторых, нами были выделены четыре ключевые тенденции, характеризующие воздействие «цифры» на российский политический протест. Первая состоит в том, что в последнее десятилетие, начиная с «Болотного» движения 2011-2012 гг., социальные сети Рунета стали эффективным инструментом протестной мобилизации различных сегментов российского общества. Вторая тенденция заключается в следующем: цифровизация способствовала активной политизации российской молодежи, которая стала главным субъектом политического протеста в Москве, Санкт-Петербурге и других крупных городах России. Третья тенденция состоит в открывшейся возможности ретрансляции протестных настроений в виртуальную плоскость, их частичного «растворения» в интернет-пространстве, что снижает политические риски для действующей власти. Четвертая тенденция - всплеск активности российской несистемной оппозиции, которая получила возможность формировать собственную альтернативную политическую повестку дня посредством социальных медиа.

\section{Список литературы}

Бродовская Е.В. 2019. Цифровые граждане, цифровое гражданство и цифровая гражданственность. - Власть. Т. 27. № 4. С. 65-69.

Володенков С.В. 2019. Big data как инструмент воздействия на современный политический процесс: особенности, потенциал и акторы. - Журнал политических исследований. № 1. С. 7-13.

Карзубов Д.Н. 2016. Социальный протест в Минеральных Водах: результаты конфликтологического анализа. - Гуманитарные науки. Вестник Финансового университета. № 6. С. 60-64.

Козлова И.С. 2020. Потенциал использования социальных сетей в протестных акциях в России. - Известия высших учебных заведений. Социология. Экономика. Политика. № 2. С. 99-110.

Косоруков А.А., Котлярова Т.Ю. 2018. Информационно-коммуникационные технологии как фактор трансформации публичной сферы современного общества. - Тренды и управление. № 4. С. 88-96.

Коэн Дж., Шмидт Э. 2013. Новый цифровой мир: как технологии меняют жкизнь людей, модели бизнеса и понятие государств (пер. с англ. С. Филина). М.: Манн, Иванов и Фербер. 367 с.

Пономарев Н.А., Белов С.И., Майлис А.А. 2018. Противодействие росту вовлеченности молодежи в радикальный политический протест (на материалах массовых выступлений 2017 г.). - Государственное управление. Электронный вестник. № 67. С. 150-169.

Пырма Р.В. 2019. Протестные настроения российской молодежи в цифро- 
вой сети. - Гуманитарные науки. Вестник Финансового университета. № 6(42). C. $100-110$.

Титов В.В. 2020. Стратегии социального протеста молодежи в Рунете: сравнительный анализ поколений Y и Z. - Мониторинг общественного мнения: экономические и социальные перемены. № 3. С. 139-158.

Шатилов А.Б. 2014. «Диванные войска» как новая форма информационнопропагандистского сопровождения политических и военных конфликтов в начале XXI века. - Власть. № 7. С. 56-58.

Graham C., Pettinato S. 2002. Frustrated Achievers: Winners, Losers and Subjective Well-Being in New Market Economies. - Journal of Development Studies. Vol. 38. No. 4. P. 100-140.

IGNATOVSKIY Yaroslav Rinatovich, Political Scientist, General Director of Analytical Center «PolitGen» (Russia, St.Petersburg; hindutime@mail.ru)

\section{THE ROLE OF DIGITALIZATION IN THE TRANSFORMATION OF THE RUSSIAN POLITICAL PROTEST}

Abstract. The study identifies four key trends, which show the impact of digitalization on Russian political protest. The first is that Runet social networks have become an instrument of protest mobilization of different segments of Russian society. The second trend shows that digitalization has contributed to the growth of protest sentiments among young people. The third trend shows the possibilities of transfer of protest moods to the virtual space. The fourth trend is a growth of the activity of the non-systemic opposition, which gets the opportunity to create an alternative political agenda through social media on the Runet.

Keywords: digitalization, political protest, protest moods, simulative reality, digital natives, Runet 